\title{
Evaluation of the key words used in articles of the Acta Cirurgica Brasileira from 1997 to $2012^{1}$
}

\author{
Avaliação dos descritores utilizados nos artigos da \\ Acta Cirúrgica Brasileira de 1997 a 2012
}

\author{
Renan Kleber Costa Teixeira ${ }^{\mathrm{I}}$, Thiago Barbosa Gonçalves', Vitor Nagai Yamaki', Nara Macedo Botelho"I, Marcus Vinicius \\ Henriques Brito ${ }^{\text {II }}$ \\ IGraduate student, Experimental Surgery Laboratory. School of Medicine, UEPA, Belem-PA, Brazil. Conception, design, acquisition of data and \\ drafting the manuscript. \\ IIPhD, Associate Professor, School of Medicine, UEPA, Belem-PA, Brazil. Intellectual, scientific content of the study, analysis and interpretation of \\ data, critical revision.
}

\section{ABSTRACT}

PURPOSE: To evaluate the key words used in Acta Cirurgica Brasileira from 1997 to 2012.

METHODS: All the key words of all articles published in regular issues between 1997 and 2012 were analyzed, ensuring that these key words were in the MeSH database (Medical Subjects Headings) and the most used subject headings and most wrong repeated key words were ranked.

RESULTS: 4230 key words used in 990 articles were analyzed. Only 579 key words (13.68\%) were not in the MeSH database, considering that there was a statistically significant decrease over the years $(p<0.001)$. The three most used key words were Rats, Dogs and Wound healing. Among the wrong ones, the key words were Adhesions, Experimental surgery and Anatomosis.

CONCLUSION: There was a gradual improvement in the amount of key words used that belonged to the MeSH database, and there were 618 articles $(62.42 \%)$ with all key words correct.

Key words: Medical Subject Headings. Terminology. Abstracting and Indexing as Topic.

\section{RESUMO}

OBJETIVO: Avaliar os descritores utilizados na Acta Cirúrgica Brasileira entre os anos de 1997 até 2012.

MÉTODOS: Foram analisados os descritores de todos os artigos publicados em fascículos regulares entre os anos de 1997 a 2012 , verificando se estes constavam no MeSH e foi feito um ranking dos descritores mais utilizados e dos termos equivocados mais repetidos. RESULTADOS: Foram analisados 4230 descritores, presentes em 990 artigos. Apenas 579 (13,68\%) dos descritores estavam fora da base do MeSH, sendo que houve uma diminuição estatisticamente significante com o passar dos anos ( $<<0.001$ ). Os três descritores mais utilizados foram Rats, Dogs e Wound healing, já dentre as equivocadas foram os termos Adhesions, Experimental surgery e Anatomosis.

CONCLUSÃO: Houve uma melhora progressiva na quantidade de termos utilizados que pertenciam a base do MeSH, havendo 618 artigos $(62,42 \%)$ com todos os descritores corretos.

Descritores: Descritores em Medicina. Terminologia. Resumos e Indexação como Assunto. 


\section{Introduction}

The extensive dissemination to the scientific community is what the real contribution of scientific research represents ${ }^{1}$. The publication of results is indispensable, since recording manuscript knowledge has been the most powerful means found by humanity to convey information. Cultures that have not developed the habit of writing were lost in time, demonstrating that the communication of knowledge, in these cases, did not perpetuate for long periods ${ }^{2}$.

With the advent of the Internet, a greater access to the various national and international databases was achievable, facilitating access to a wider range of articles. However, it is necessary to further refine the search in order to find more specific articles related to the subjects to be searched. Then, some mechanisms for finding scientific papers were created, one being the use of the Medical Subject Headings database (MeSH) ${ }^{3}$.

The MeSH database appeared in 1963 and was elaborated by the American National Library of Medicine. It is a set of key words standardized and indexed in a database, which must be consulted and used for the production of scientific articles. The $\mathrm{MeSH}$ database is in a continuous process of updating, being the key words gradually added and removed from their indexation, in order to facilitate the search for scientific articles ${ }^{4}$.

Although the use of key words indexed in the MeSH database is of great importance, authors of scientific manuscripts often consult key words in other articles, or even create their own key words ${ }^{5}$, culminating in a mismatch of much of these key words with the MeSH database ${ }^{6}$.

This mistaken use of key words results in a barrier to the location of several relevant searches and thus these key words end up not being cited $^{7}$. As a consequence, a significant portion of scientific production remains submerged and unknown ${ }^{8}$.

The Acta Cirúrgica Brasileira journal, founded in 1986, is currently the main vehicle for publication of research in the area of Experimental Surgery in Brazil ${ }^{9}$. In recent years, the journal has shown an explosive growth, and is now classified as A2, according to the Co-ordination of Improvemenr for Higher Academic Staff CAPES (a government agency linked to the Brazilian Ministry of Education in charge of promoting high standards for post-graduate courses in Brazil), in medicine class III. Currently, it has an impact factor of $0.5^{10}$ with a significant amount of citations of its published articles. This index has been showing gradual increase over the years ${ }^{8}$.

"Normalizing is salutary"11, thus the correct use of key words is of fundamental importance, which in addition to leverage the growth of scientific journals improves its impact factor
Therefore, the objective of this paper is to evaluate the correct use of key words in articles published by the Acta Cirurgica Brasileira from 1997 to 2012.

\section{Methods}

This work is characterized as observational and transversal, in which all key words used by authors-who have published articles in regular issues of the Acta Cirurgica Brasileira from 1997 to 2012, referring to issues available by SciELO (Scientific Electronic Library Online) database-were analyzed.

The key words used were accessed in abstracts of published articles. The criteria for inclusion of articles were to possess at least one key word in English and being published in regular issues of the Acta Cirurgica Brasileira journal. Articles that had no key words or possessed only key words in Portuguese were excluded.

In data collection, it was examined whether the key words of articles published in the journal were present in the MeSH database. For this purpose, the key word was rewritten exactly as in the MeSh website, 2012 version (http://www.ncbi.nlm.nih.gov/ mesh). In addition, the key words were ordered according to the amount of times that they were used, besides ranking the wrong key words most used by the authors of articles published in the journal.

Pearson's Linear Correlation Test was used to verify the variance in the amount of articles and key words per issue, in addition to the evolution of the percentage of wrong key words and the evolution of articles with all key words indexed in the MeSH database, relating these variables with the years of publication. In order to consider data as significant, $\mathrm{p}<0.01$ was adopted.

\section{Results}

The Acta Cirurgica Brasileira portfolio comprises 1597 articles published in regular issues and supplements from 1986 to 2012. Currently, this journal is indexed in SciELO database, in which articles published from 1997 to 2012 can be found. With regard to the regular issues published during this periodwith exception of the supplements-there are 1088 articles, among which 94 do not have key words and four of them have only key words in Portuguese. In this way, the sample studied comprised 990 articles.

Until 2001, four regular issues were published per year and this number has increased to six issues per year from 2002. In 2012, only one issue was studied. The average number of articles 
published per issue was $12.2 \pm 2.77$.

Adding the key words of the 990 articles of the sample searched, there were a total of 4230 key words. The maximum and minimum numbers of key words in each article were 11 and 1 , respectively. The average of key words per article was 4.27 and the average of key words per year was 264.37. The amount of articles per issue, key words per year and key words per year per article are demonstrated in Table 1.

TABLE 1 - Number of articles and key words per year of publication of the Acta Cirurgica Brasileira.

\begin{tabular}{cccc}
\hline Year & $\begin{array}{c}\text { Articles } \\
\text { by issue* }\end{array}$ & $\begin{array}{c}\text { Key words } \\
\text { per year }\end{array}$ & $\begin{array}{c}\text { Key words } \\
\text { per year per } \\
\text { article* }\end{array}$ \\
\hline $\mathbf{1 9 9 7}$ & 11.25 & 163 & 3.62 \\
$\mathbf{1 9 9 8}$ & 9.25 & 142 & 3.83 \\
$\mathbf{1 9 9 9}$ & 9.25 & 141 & 3.81 \\
$\mathbf{2 0 0 0}$ & 8.75 & 142 & 4.05 \\
\hline $\mathbf{2 0 0 1}$ & 10.25 & 159 & 3.87 \\
$\mathbf{2 0 0 2}$ & 9 & 230 & 4.25 \\
\hline $\mathbf{2 0 0 3}$ & 12.83 & 296 & 3.84 \\
\hline $\mathbf{2 0 0 4}$ & 13.83 & 333 & 4.01 \\
\hline $\mathbf{2 0 0 5}$ & 12.5 & 325 & 4.33 \\
\hline $\mathbf{2 0 0 6}$ & 12 & 293 & 4.07 \\
\hline $\mathbf{2 0 0 7}$ & 13.33 & 352 & 4.4 \\
\hline $\mathbf{2 0 0 8}$ & 13.5 & 354 & 4.37 \\
\hline $\mathbf{2 0 0 9}$ & 13.33 & 377 & 4.71 \\
\hline $\mathbf{2 0 1 0}$ & 15.33 & 422 & 4.58 \\
\hline $\mathbf{2 0 1 1}$ & 14.5 & 427 & 4.91 \\
\hline $\mathbf{2 0 1 2}$ & 14 & 74 & 5.28 \\
\hline $\mathbf{T 0 t a l}$ & 12.22 & 4230 & 4.27 \\
\hline & & & \\
\hline
\end{tabular}

Source: Search Protocol

$\mathrm{p}<0.001$ (Pearson's Linear Correlation Test)

Considering the ranking of the 10 key words mostly used from 1997 to 2012 in the Acta Cirurgica Brasileira, it can be observed that three of them relate to animals and two refer to organs. On the other hand, according to the MeSH database, when the ranking of the 10 wrong key words-mostly used by authors of articles published in the Acta Cirurgica Brasileira-is observed, a word spelled in Portuguese stands out (Table 2).
TABLE 2 - Lists of the key words most widely used and, according to the MeSH database, wrong key words most used in articles of the Acta Cirurgica Brasileira, between 1997 and 2012.

\begin{tabular}{|c|c|c|c|c|c|}
\hline & Key word & $\mathbf{N}$ & & $\begin{array}{c}\text { Wrong key } \\
\text { word }\end{array}$ & $\mathbf{N}$ \\
\hline $\mathbf{1}^{\mathrm{o}}$ & Rats & 345 & $1^{0}$ & Adhesions & 9 \\
\hline $2^{\circ}$ & Dogs & 68 & $2^{\circ}$ & $\begin{array}{l}\text { Experimental } \\
\text { surgery }\end{array}$ & 9 \\
\hline $3^{\circ}$ & Wound healing & 67 & $3^{\circ}$ & Anastomosis & 7 \\
\hline $4^{\circ}$ & Ischemia & 64 & $4^{\circ}$ & Healing & 7 \\
\hline $5^{\circ}$ & Rabbits & 59 & $5^{\circ}$ & $\begin{array}{c}\text { Video- } \\
\text { laparoscopy }\end{array}$ & 5 \\
\hline $6^{\circ}$ & Reperfusion & 44 & $6^{\circ}$ & Disease models & 4 \\
\hline $7^{\circ}$ & Liver & 43 & $7^{\circ}$ & Mesh & 4 \\
\hline $8^{\circ}$ & $\begin{array}{c}\text { Animal } \\
\text { experimentation }\end{array}$ & 39 & $8^{\circ}$ & Cadáver & 3 \\
\hline $9^{\circ}$ & Colon & 36 & $9^{\circ}$ & $\begin{array}{c}\text { Hepatic } \\
\text { regeneration }\end{array}$ & 3 \\
\hline $10^{\circ}$ & Surgery & 32 & $10^{\circ}$ & Experimental & 3 \\
\hline
\end{tabular}

Source: Search Protocol

$\mathrm{N}$ : Number of times that the key word was used. MeSH: Medical Subject Headings.

According to the MeSH database, the total of wrong key words was 579 , which corresponds to $13.68 \%$ of the totality of key words used from 1997 to 2012. With respect to the sample of articles researched, 618 had all key words correct. At the same time, there were only 15 articles with all key words wrong; corresponding to $62.42 \%$ and $1.5 \%$ of all articles searched in this period, respectively.

Figure 1 represents the development of the amount of key words mistakenly used per year, as well as the amount of articles with all key words correct. Both developments were statistically significant $(\mathrm{p}<0.001)$. 


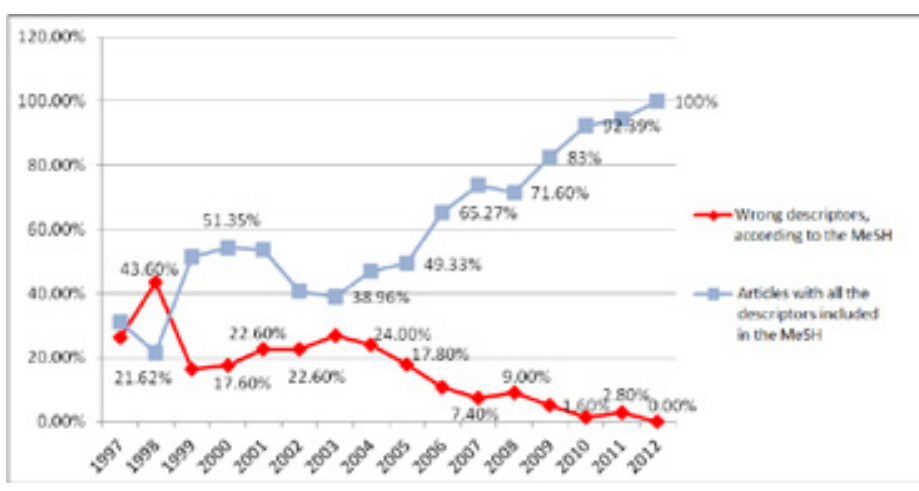

FIGURE 1 - Percentage evolution of the number of wrong key words, according to the MeSH database and the year of publication, and percentage of articles with all key words correct published in the Acta Cirurgica Brasileira.

MeSH: Medical Subject Headings

$\mathrm{p}<0.001$ (Pearson's Linear Correlation Test)

\section{Discussion}

The Acta Cirurgica Brasileira began to be elaborated in 1986. Since then, 1597 articles were published among regular issues and supplements. However, it was only in 1997 that it started to be indexed in SciELO database. This database currently comprises articles from 1997 to $2012^{12}$. The totality of these articles, 1088 (68.12\%), were studied and 98 (8.75\%), corresponding to editorials and other articles without English key words, were excluded. Thus, the sample studied consisted of 990 articles.

There was an increase in the number of articles by issues over the years in the Acta Cirurgica Brasileira, showing the importance gained by the journal, reflecting also the editorial policy that always progressed through constant improvements, culminating in the indexation of the journal into databases such as Medline and SciELO. In addition to being classified as A2 in medicine III and B3 in medicine I and II, showing an impact factor of 0.5 , the Acta Cirurgica Brasileira became one of the major national journals in the area of surgery, especially in the experimental field ${ }^{8,10}$.

In the guidelines for authors of the journal studied, a minimum or maximum number of key words, which are to be used in articles submitted, are not indicated. However, there has been an increase in the use of these key words over the years analyzed, showing that the authors realized the importance of using key words to make it easier to find the article and facilitate its citation ${ }^{13}$.

In the ranking of the key words most cited in the Acta Cirurgica Brasileira, it is possible to observe the presence of three animals and two organs, showing the use of key words that prioritize the designation of the objects studied in the article. This fact is of great value, especially in the field of experimental surgery. In addition, the key words referring to animals are consistent with the order in which the main animals are used in experimental surgery.

In the list of the most used wrong key words, a low amount of repetitions of a single key word can be observed. This shows that the use of key words out of the MeSH database is generally not consistent with the journal's editorial policy. It is also possible to detect that many mistakenly used key words have only a part of it wrong and not the whole key word, as, for example, "anastomosis" which was used instead of "surgical anastomosis" (Figure 2).

\begin{tabular}{cc}
\hline Key word Used & Correct Key word \\
\hline Adhesions & Tissue Adhesions \\
Experimental surgery & Animal Experimentation \\
Anastomosis & Surgical Anastomosis \\
Healing & Wound Healing \\
Videolaparoscopy & Video-Assisted Surgery \\
Disease models & Disease Models, Animal \\
MeSH & Medical Subject Headings \\
Cadáver & Cadaver \\
Hepatic regeneration & Liver Regeneration \\
Experimental & Animal Experimentation \\
\hline
\end{tabular}

FIGURE 2 - List of key words present in the MeSH database that correspond to the ten wrong key words mostly used in the Acta Cirurgica Brasileira.

Source: search protocol

Only 579 (13.68\%) key words were not in the MeSH database, which is a value considered low in relation to the work of Oliveira et al. ${ }^{13}$ and Rosas ${ }^{1}$, who found $56.23 \%$ and 53\% nonindexed key words, respectively. This demonstrates the importance given to key words by the journal's editorial board and also on the part of researchers who submit their articles to this journal. The correct use of key words is of great value to the authors and to the journal, because this is a mechanism that aims to facilitate finding the article, causing it to be read and cited more often.

Teixeira and Botelho ${ }^{7}$, studying key words of two Brazilian surgery journals, found $94.64 \%$ of key words indexed. However, they only studied the key words of articles published in 2010, so this result is similar to that found in this study which found $98.4 \%$ of the key words analyzed present in the MeSH database.

The low number of wrong key words published in the journal was also reflected in the amount of articles with all the key 
words present in the database, which was of 618 articles $(62.42 \%)$. This can also be verified by the decreasing amount of wrong key words over the years and the fact that all key words of the last issue analyzed were present in the MeSH database ${ }^{5}$.

Rosas et al. ${ }^{1}$, in a study of master's theses key words in respiratory diseases, found just $14 \%$ of theses with all key words correct. The divergence between that study and the present one occurs due to a greater appreciation of the correct use of key words by authors who submit articles to the Acta Cirurgica Brasileira, in addition to the corrections made by the reviewers and editors of the journal. This results in an improvement in the quality of the journal studied, which in one of its issues published an explanation about how to use properly the database of key words ${ }^{14}$.

It is known that the ideal is that all journals have $100 \%$ of key words used in accordance with the MeSH database guidelines. However, it must also be taken into consideration that there is still a need to continuously update and revise key words on the part of databases. This was initially appointed by Azevedo, Población and Goldenberg ${ }^{15}$ and was most recently demonstrated by the study of Ferreira et al. ${ }^{16}$, who proposed to include the term "superficial musculoaponeurotic system" in the MeSH database, showing the great importance of such a term for the database.

It should be observed that this study has a limitation by the fact of having used the key words present in the abstracts of articles from the electronic version of the journal, considering that from the online publication to the printing of the journal some small errors can be corrected, as, for example, key words mistakenly used. However, the results presented by this study are significant, since the key words used in the electronic version are those that will be used when looking for articles in databases of articles research websites.

\section{Conclusions}

Among the 4230 key words studied in 990 articles of the Acta Cirurgica Brasileira, 579 key words were not present in the MeSH database; however, 618 articles had all the key words indexed in the MeSH database. The main key words used in the Acta Cirurgica Brasileira were Rats, Dogs and Wound healing. Now, in the ranking of wrong key words, it was observed that they are repeated few times and have a great diversity.

\section{References}

1. Rosas P, Guimarães CA, Judice LF, Ferreira CAC, Valio EBM. Descritores em Ciências da Saúde nas teses e dissertações de mestrado, na área de doenças respiratórias. Acta Cir Bras.
1999;14(1):43-6.

2. Timi JRR. A importância do uso dos descritores nas publicações médicas. J Vasc Bras. 2005;4(2):114-5.

3. Castro E. Terminologia, palavras-chaves, descritores em saúde: qual a sua utilidade? J Bras AIDS. 2001;2(1):51-61.

4. Lowe HJ, Barnett GO. Understanding and using the medical subject headings $(\mathrm{MeSH})$ vocabulary to perform literature searches. JAMA. 1994;271(14):1103-8.

5. Brandau R, Monteiro R, Braile DM. Importância do uso correto dos descritores nos artigos científicos. Rev Bras Cir Cardiovasc. 2005;20(1):7-9.

6. Teixeira RKC, Chaves RF, Botelho NM. A importância dos Descritores em Ciência da Saúde. Rev Para Med. 2010;24(1):5-6.

7. Teixeira RKC, Botelho NM. Avaliação dos unitermos utilizados em dois periódicos nacionais de cirurgia. Rev Para Med. 2011;25(2):347.

8. Medeiros AC. O fator de impacto da Acta Cirúrgica Brasileira. Acta Cir Bras. 2003;18(2):74-5.

9. Goldenberg S. Mensagem do Presidente. Acta Cir Bras. 1997;12(2):83.

10. Brasil. Coordenação de Aperfeiçoamento de Pessoal de Nível Superior (CAPES). Webqualis. 2011. Disponível em <http:// webqualis.org.br/>. Acesso em 1 de dezembro de 2011.

11. Goldenberg S. Normalizar é salutar. Acta Cir. Bras. 2000;15(2):80.

12. Goldenberg S, Goldenberg A, Fino TPM. Evolução histórica da revista Acta Cirúrgica Brasileira (1986-2005). Acta Cir Bras. 2006;21(1):1-4.

13. Oliveira EFB, Oliveira HB, Azevedo JLMC, Fagundes DJ. Avaliação dos descritores na angiologia e cirurgia vascular em artigos publicados em dois periódicos nacionais. Acta Cir Bras. 2003;18(1):62-72.

14. Pellizon RF. Pesquisa na área da saúde: 1 - base de dados DeCS (Descritores em Ciências da Saúde). Acta Cir Bras. 2004;19(2):15363.

15. Azevedo JLMC, Poblácion DA, Goldenberg S. Descritores (unitermos) nos artigos científicos. Acta Cir Bras. 1990;5(2):35-54.

16. Ferreira LM, Locali RF, Lapin GAF, Hochman B. Importance to include the term superficial musculoaponeurotic system in medical subject headings and in the international anatomical nomenclature. Acta Cir Bras. 2011;26(3):242-6.

\section{Correspondence:}

Thiago Barbosa Gonçalves

Rua Dom Romualdo Coelho, 722/2102

66055-190 Belém - PA Brasil

Tel.: (55 91)8847-5059

tbgow@hotmail.com

Received: December 20, 2011

Review: February 21, 2012

Accepted: March 19, 2012

Conflict of interest: none

Financial source: none

${ }^{1}$ Research performed at Experimental Surgery Laboratory. School of Medicine, State University of Para (UEPA), Belem-PA, Brazil. 